\title{
Keratinizing Primary Intraosseous Squamous Cell Carcinoma -Solid Type
}

National Cancer Institute

\section{Source}

National Cancer Institute. Keratinizing Primary Intraosseous Squamous Cell Carcinoma -

Solid Type. NCl Thesaurus. Code C7498.

A squamous cell carcinoma that arises centrally from the jaw. It is characterized by a solid pattern, keratin production, infiltration of the marrow spaces, and osseous resorption. 